\title{
Several pathways of hydrogen peroxide action that damage the E. coli genome
}

\author{
Nasser Ribeiro Asad ${ }^{1}$, Lidia Maria Buarque Oliveira Asad ${ }^{1}$, Carlos Eduardo Bonacossa de Almeida ${ }^{3}$, \\ Israel Felzenszwalb ${ }^{1}$, Januário Bispo Cabral-Neto ${ }^{2}$ and Alvaro Costa Leitão ${ }^{2}$ \\ ${ }^{1}$ Universidade do Estado do Rio de Janeiro, Departamento de Biofisica e Biometria, \\ Instituto de Biologia Roberto Alcantara Gomes, Rio de Janeiro, RJ, Brazil. \\ ${ }^{2}$ Universidade Federal do Rio de Janeiro, Instituto de Biofisica Carlos Chagas Filho, \\ Rio de Janeiro, RJ, Brazil. \\ ${ }^{3}$ Comissão Nacional de Energia Nuclear, Divisão de Monitoração Individual, \\ Instituto de Radioproteção e Dosimetria, Rio de Janeiro, RJ, Brazil.
}

\begin{abstract}
Hydrogen peroxide is an important reactive oxygen species (ROS) that arises either during the aerobic respiration process or as a by-product of water radiolysis after exposure to ionizing radiation. The reaction of hydrogen peroxide with transition metals imposes on cells an oxidative stress condition that can result in damage to cell components such as proteins, lipids and principally to DNA, leading to mutagenesis and cell death. Escherichia colicells are able to deal with these adverse events via DNA repair mechanisms, which enable them to recover their genome integrity. These include base excision repair (BER), nucleotide excision repair (NER) and recombinational repair. Other important defense mechanisms present in Escherichia coli are OxyR and SosRS anti-oxidant inducible pathways, which are elicited by cells to avoid the introduction of oxidative lesions by hydrogen peroxide. This review summarizes the phenomena of lethal synergism between UV irradiation ( $254 \mathrm{~nm}$ ) and $\mathrm{H}_{2} \mathrm{O}_{2}$, the cross-adaptive response between different classes of genotoxic agents and hydrogen peroxide, and the role of copper ions in the lethal response to $\mathrm{H}_{2} \mathrm{O}_{2}$ under low-iron conditions.
\end{abstract}

Key words: hydrogen peroxide, cross-adaptive response, lethal synergism, copper and iron.

Received: February 13, 2004; Accepted: February 19, 2004.

\section{General Aspects}

The appearance of aerobic forms of life was an important step in the evolutionary process, since oxygen consumption leads to the production of ten-fold more energy from glucose than does anaerobic metabolism (Meneghini, 1987). However, this process imposes constraints on cell viability, because of the generation of reactive oxygen species during respiration.

The consecutive univalent reduction of molecular oxygen to water produces three active intermediates: superoxide anion $\left(\mathrm{O}_{2}^{-\bullet}\right)$, hydrogen peroxide $\left(\mathrm{H}_{2} \mathrm{O}_{2}\right)$ and hydroxyl radical $\left(\mathrm{OH}^{\circ}\right)$. These intermediates, collectively referred to as reactive oxygen species (ROS) are potent oxidants of lipids, proteins, and nucleic acids (Halliwell and Gutteridge, 1984; Mello-Filho and Meneghini, 1985; Me-

Send correspondence to Dr. Alvaro C. Leitão. Universidade Federal do Rio de Janeiro, Instituto de Biofísica Carlos Chagas Filho, Centro de Ciências da Saúde, Bloco G, Ilha do Fundão, 21949-900 Rio de Janeiro, RJ, Brasil. E-mail: acleitao@biof.ufrj.br. neghini, 1988). Among the oxidative DNA lesions, one of the major classes of DNA damage leads to modification in purine and pyrimidine bases, together with oligonucleotide strand breaks, DNA-protein cross-links and abasic sites. Increasing evidence suggests that the cumulative damage caused by ROS contributes to numerous degenerative diseases associated with aging, such as atherosclerosis, rheumatoid arthritis and cancer (Ames et al., 1993; Halliwell and Gutteridge, 1999).

Living organisms have developed specific mechanisms to prevent the production and effects of ROS. The reduction of $\mathrm{O}_{2}$ by cytochrome oxidase without yielding ROS, the superoxide dismutase catalysis of $\mathrm{O}_{2}{ }^{-\bullet}$ into $\mathrm{H}_{2} \mathrm{O}_{2}$ through a dismutation reaction, the decomposition of $\mathrm{H}_{2} \mathrm{O}_{2}$ by catalase and peroxidases, and the scavenging of ROS by some vitamins comprise part of the set of cellular antioxidant defenses (Halliwell and Gutteridge, 1999). Synthesis of the enzymes that catalyze these reactions is a part of the adaptive response triggered by the stress posed by ROS. 
Despite these cellular defenses, many lesions can be produced in cellular targets, mainly in the DNA molecule, leading to mutagenesis and cell death. However, cells are able to deal with these adverse events via DNA repair mechanisms, which enable them to recover their integrity. These include base excision repair (BER), nucleotide excision repair (NER) and recombinational repair (Miles and Sancar, 1989).

Several studies indicate that the killing of $E$. coli cells exposed to $\mathrm{H}_{2} \mathrm{O}_{2}$ is mainly due to damage to DNA (Imlay and Linn, 1986; Imlay and Linn, 1988; Hagensee and Moses, 1989; Asad and Leitão, 1991) and a wide variety of DNA lesions are formed (Halliwell and Gutteridge, 1999) as a by-product of the $\mathrm{H}_{2} \mathrm{O}_{2}$ reaction. Some of these lesions are miscoding acting as an important source of mutagenesis in aerobically growing cells.

Participation of $\mathrm{OH}^{\circ}$ as the main damaging agent has been suggested by studies using scavengers of $\mathrm{OH}^{\circ}$. Repine et al. (1981) and Brakely et al. (1990) have demonstrated that dimethyl sulfoxide partially inhibits DNA base damage by $\mathrm{H}_{2} \mathrm{O}_{2}$, and Brandi et al. (1989) have noted that $E$. coli bacteria are partially protected against the lethal effects of $\mathrm{H}_{2} \mathrm{O}_{2}$ by pretreatment with ethanol, dimethyl sulfoxide, or thiourea.

The induction of DNA damage by $\mathrm{H}_{2} \mathrm{O}_{2}$ in E. coli as well as in mammalian cells can be either impaired or enhanced by the presence of transition metal ion chelators (Mello-Filho and Meneghini, 1985: Asad and Leitão, 1991). In addition, $\mathrm{H}_{2} \mathrm{O}_{2}$ can cause membrane lesions through lipid peroxidation and, by promoting alterations in several amino acids can lead to the inactivation of enzymes (Farr and Kogona 1991).

Recent reviews on the mechanisms of oxidative DNA damage and repair have focussed on prevention and repair (Cooke et al., 2003), biochemical features (Cadet et al., 2003), substrate specificities for glycosylases (Dizdaroglu, 2003), biological consequences (Wallace, 2002: Bjelland and Seeberg, 2003) and the role of iron (Kruszewski, 2003).

In this review, we discuss several aspects of DNA damage and cellular inactivation induced by hydrogen peroxide; the importance of transition metals such as iron and copper in this context; DNA repair pathways involved in the cellular response to $\mathrm{H}_{2} \mathrm{O}_{2}$, and related antioxidant cell defenses.

\section{$\mathrm{H}_{2} \mathrm{O}_{2}$ and transition metals}

$\mathrm{H}_{2} \mathrm{O}_{2}$ reacts with $\mathrm{O}_{2}^{-\bullet}$ resulting in $\mathrm{OH}^{\bullet}$ production through the so-called Haber-Weis cycle. However, this reaction depends on the presence of transition metals such as $\mathrm{Cu}^{+}$and/or $\mathrm{Fe}^{2+}$, which work as reducing agents, according to the reactions below (Kehrer, 2000).

$$
\begin{aligned}
\mathrm{Fe}^{3+}+\mathrm{O}_{2}^{-} & \rightarrow \mathrm{Fe}^{2+}+\mathrm{O}_{2} & \text { eq. (I) } \\
\mathrm{Fe}^{2+}+\mathrm{H}_{2} \mathrm{O}_{2} & \rightarrow \mathrm{Fe}^{3+}+\mathrm{OH}^{-}+\mathrm{OH}^{-} & \text {eq. (II) } \\
\text { Net reaction : } \mathrm{O}_{2}^{-\bullet}+\mathrm{H}_{2} \mathrm{O}_{2} & \rightarrow \mathrm{O}_{2}+\mathrm{OH}^{-}+\mathrm{OH}^{\cdot} & \text { eq. (III) }
\end{aligned}
$$

$\mathrm{H}_{2} \mathrm{O}_{2}$, per se, is considered a weak oxidant agent. Nevertheless, it easily crosses the cellular membrane and reacts with transition metals, generating $\mathrm{OH}^{\circ}$. Evidence for the importance of transition metals comes from studies with chelators such as dipyridyl, phenanthroline and desferioxamine (Fe chelators) and neocuproine (a $\mathrm{Cu}$ chelator) (Brandi et al., 1989; Brakely et al., 1990; Hallywell and Gutteridge, 1999). Pretreatment with iron chelators protects both prokaryotic and eukaryotic cells against the lethal effects of $\mathrm{H}_{2} \mathrm{O}_{2}$ (Mello-Filho and Meneghini, 1985; Imlay and Linn, 1988; Asad and Leitão, 1991). Additionally, cultures of Staphylococcus aureus are more sensitive to $\mathrm{H}_{2} \mathrm{O}_{2}$ when iron is added to the culture media (Repine et al., 1981) and in E. coli cultures the same is observed (Touati et al., 1995).

In E. coli the metabolism of iron is involved in the cellular antioxidant response. A transcription factor denoted Fur, the global repressor of ferric ion uptake, regulates about 30 genes implicated in iron uptake from the environment (Braun, 1997; Braun et al., 1998). Most Fur-regulated genes are derepressed in low iron concentrations and repressed when a high concentration of iron is present (Hantke, 1981; Hantke, 2002). The finding that fur mutants are sensitive to $\mathrm{H}_{2} \mathrm{O}_{2}$ and that they suffer an increase in oxidative DNA damage leading to mutations under aerobic conditions supports the hypothesis that Fur has a role in the defense against oxidative stress (Touati et al., 1995). Furthermore, the regulators of $E$. coli responses to oxidative stress, OxyR and SoxRS, activate the expression of Fur and suggest that control of iron metabolism in E. coli is an integral part of the antioxidant response (Zheng et al., 1999)

\section{DNA Repair Pathways and Antioxidant Defense Systems}

\section{Base excision repair (BER)}

Lesions produced by $\mathrm{H}_{2} \mathrm{O}_{2}$ are typically repaired by base excision repair (BER) mechanisms. This kind of DNA repair is initiated by DNA glycosylases, enzymes that recognize the modified bases and act by cleaving the glycosylic bond, thereby removing the damaged base from the sugar phosphate backbone and, as a result, producing an apurinic/apyrimidinic (AP) site (Sancar and Sancar, 1988).

Some DNA glycosylases also display a class I AP lyase activity that incises the phosphodiester linkage on the 3 ' side of the AP lesion and generates a 5'-phosphate group and a 3 '-terminus that needs removal by a class II AP endonuclease/3'-diesterase prior to repair synthesis and ligation (Piersen et al., 2000). The cleavage of AP sites can also be catalyzed by class II AP endonucleases which incise the 5' side of the AP site, leaving a 3'-OH terminus and a 5'-abasic residue that is removed by a deoxyribophosphodiesterase (dRPase) (Mol et al., 2000).

In $E$. coli two enzymes are representative of the class I AP lyases, the Fpg/MutM DNA glycosylase, product of the 
fpg/mutM gene, which recognizes primarily oxidized purines, and the DNA endonuclease III, product of the nth gene, which recognizes primarily oxidized pirimidines. Interestingly, the E. coli repair-deficient $f p g / m u t M$, as well as the $n$th mutants, are not more sensitive to killing by $\mathrm{H}_{2} \mathrm{O}_{2}$ than wild-type cells (Cunningham and Weiss, 1985; Boiteux and Huisman, 1989). Subsequently, endonuclease VIII and IX were purified from endonuclease III-deficient E. coli cells (Wallace et al., 1988; Melamede et al., 1994). Endonuclease VIII was found to exhibit a thymine glycol DNA glycosylase activity as well as an AP lyase activity. Endonuclease IX recognizes urea residues and $\beta$-ureidoisobutyric acid in DNA; however, DNA containing thymine glycol or dihydrothymine is not a substrate for this enzyme (Friedberg et al., 1995). Later, the gene for endonuclease VIII (nei) was isolated (Jiang et al., 1997; Saito et al., 1997). Endonuclease VIII is present in extracts of $E$. coli at 5 to $10 \%$ of the level of endonuclease III and is responsible for the repair of $10 \%$ of the thymine glycol in E. coli (Wallace et al., 1988; Wallace, 1988).

The nth nei double mutants are hypersensitive to $\mathrm{H}_{2} \mathrm{O}_{2}$ (Jiang et al., 1997). Moreover, endonuclease VIII can recognize 8-oxo-7,8-dihydroxyguanine (8-oxoG) lesions, a kind of lesion also recognized by Fpg protein (Blaisdell et al., 1999). The multiplicity of DNA glycosylases that recognize and attack sites of oxidative damage in DNA confirms the importance of this form of base damage.

Class II AP endonucleases of $E$. coli are mainly represented by the exonuclease III, the $x t h A$ gene product, and endonuclease IV, the $n f o$ gene product.

The role of exonuclease III in repairing oxidative damage was highlighted by the demonstration that $x$ th mutants are extremely sensitive to $\mathrm{H}_{2} \mathrm{O}_{2}$ (Demple et al., 1983). On the other hand, nfo mutants are not sensitive to $\mathrm{H}_{2} \mathrm{O}_{2}$ (Cunningham et al., 1986), and deletion of $n f o$ increases the killing of $x$ th mutants to $\mathrm{H}_{2} \mathrm{O}_{2}$, indicating that many of the repair activities of exonuclease III and endonuclease IV overlap.

Endonuclease IV normally represents about $10 \%$ of the total endonuclease activity; superoxide-generating agents induce a 10- to 20-fold increase in the level of this enzyme through the soxRS response (Chan and Weiss, 1987).

\section{Nucleotide excision repair (NER) in response to $\mathrm{H}_{2} \mathrm{O}_{2}$}

In $E$. coli, a complex of proteins encoded by the $u v r A$, $u v r B$ and $u v r C$ genes is required for lesion recognition and the dual incisions. This complex eliminates DNA lesions that cause significant distortions in the phosphodiester backbone of the molecule (Friedberg et al., 1995; Hanawalt, 2001).

This kind of repair is of fundamental importance for the correction of UV (254 nm) lesions, mainly cyclobutane pyrimidine dimers. It appears not to be related to the repair of $\mathrm{H}_{2} \mathrm{O}_{2}$ lesions, since the $u v r A B C$ mutants are not sensitive to $\mathrm{H}_{2} \mathrm{O}_{2}$ (Imlay and Linn, 1987).

The finding that the triple mutant $u v r A$ nfo $x t h A$ cannot be constructed, despite the fact that the double mutants are viable (Saporito et al., 1989), has raised the question of the connection between BER and NER DNA repair pathways. Additionally, the UvrABC complex is able to remove AP sites generated by oxidative lesions in the DNA molecule (Lin and Sancar, 1989). So, these results suggest that both repair systems correct the lesions produced by oxidant agents produced during cellular respiration.

These findings suggest that some intermediate products of base excision repair may be substrates for the UvrABC complex. This hypothesis was confirmed by Kow et al. (1990), who demonstrated the role of this complex in the repair of thymine glycols in the DNA of replicative form of phage $\Phi \times 174$. The survival of phage containing thymine glycols is lower in the $n t h u v r A$ double mutant than in the $n t h$ single mutant.

\section{SOS response}

The best-studied transcriptional response to DNA damage is the SOS response (Friedberg et al., 1995; Walker, 1996). Single-stranded DNA produced by several DNA-damaging agents and repair mechanisms can be bound by RecA protein, resulting in conversion of this protein to its activated form. Once activated, RecA interacts with LexA protein, the repressor of the SOS genes (Wagner et al., 1999). This interaction triggers the autocatalytic cleavage of LexA and consequent destruction of its ability to function as a repressor, which results in the derepression of SOS genes (Mustard and Little, 2000; Fernandez De Henestrosa et al., 2000). By using DNA microarray techniques Courcelle et al. (2001) have shown that in E. coli the expression of 43 genes is controlled by LexA.

The expression of LexA-controlled genes allows the increased phenotypic expression of mutagenesis (umuDC genes), nucleotide excision repair ( $u v r A$ and $u v r B$ genes), genetic recombination (rec $A$, recN, rec $Q$ and $r e c D$ genes), cellular filamentation ( $s u l A$ and $s u l B$ genes), and survival and mutagenesis of irradiated phages (W-reactivation and W-mutagenesis) (Friedberg et al., 1995).

A low concentration of $\mathrm{H}_{2} \mathrm{O}_{2}$ (1-3 mM) results in SOS gene induction in wild-type cells (Imlay and Linn, 1987; Goerlich et al., 1989). However, $\mathrm{H}_{2} \mathrm{O}_{2}$ can induce some SOS responses without SOS induction. An example is the cell filamentation induced by $\mathrm{H}_{2} \mathrm{O}_{2}$ in sulA and recA mutants and the mutagenesis that occurs at the same level in wild-type and $u m u C$ mutant cells treated with $\mathrm{H}_{2} \mathrm{O}_{2}$ (Imlay and Linn, 1987). On the other hand, the induction of SOS by $\mathrm{H}_{2} \mathrm{O}_{2}$ is an important event, since rec $A$ and $r e c B C$ mutant cells are very sensitive to $\mathrm{H}_{2} \mathrm{O}_{2}$ treatment probably due to the lack of recombinational repair necessary for the repair of $\mathrm{H}_{2} \mathrm{O}_{2}$-induced lesions (Imlay and Linn, 1987). Additionally, Konola et al., (2000) have shown that the ruvA 
mutants are 10- to 15-fold more sensitive to $\mathrm{H}_{2} \mathrm{O}_{2}$ (1-3 mM) than the wild-type cells. Together with RuvB, the RuvA protein generates the RuvAB complex, which stimulates strand migration in the Holliday junctions (West, 1996).

\section{Other inducible events: anti-oxidant and cross-adaptive responses triggered by $\mathrm{H}_{2} \mathrm{O}_{2}$}

Most genes encoding DNA repair enzymes that act on oxidative damage appear to be expressed constitutively in actively growing cells. This is presumably because oxidative DNA damage is continuously produced by ROS, which are normal by-products of aerobic metabolism (Demple and Harrison, 1994; Henle and Linn, 1997). However, in order to deal with elevated levels of peroxide in the environment, cells have evolved changes in metabolism that help to protect DNA from ROS.

Most inducible genes that respond to oxidative damage prevent, rather than repair DNA damage. However, a notable exception is endonuclease IV, the $n f o$ gene product, an AP endonuclease that repairs 3' phosphate residues to 3'OH groups that can prime DNA synthesis (Chaudhry et al., 1999; Izumi et al., 2000).

Two key protective responses have been described in E. coli - one controlled by soxRS genes and the other by oxyR (Tsaneva and Weiss, 1990; Storz and Imlay, 1999; Gonzalez-Flecha and Demple, 2000).

\section{The SoxRS}

Low concentrations of superoxide-generating compounds such as paraquat and menadione render the cells resistant to higher doses of these agents (Geenberg and Demple, 1989) in a manner dependent on the integrity of the soxRS locus.

The soxRS regulatory system acts in two steps, with SoxR serving both as a sensor and as an activator protein. When activated by the univalent oxidation of the $2 \mathrm{Fe}-2 \mathrm{~S}$ clusters of the protein through a not yet explained mechanism (Storz and Imlay, 1999) SoxR induces transcription of sox $S$, a positive regulator that stimulates transcription of more than 16 other superoxide responsive genes $(\mathrm{Wu}$ and Weiss, 1992; Hidalgo et al., 1995). Although this system responds to oxidative stress when cells are exposed to superoxide radical-generating agents, it is not induced by $\mathrm{H}_{2} \mathrm{O}_{2}$ (Chan and Weiss, 1987; Tsaneva and Weiss, 1990; Hidalgo et al., 1997). However, it was demonstrated that in some conditions $\mathrm{H}_{2} \mathrm{O}_{2}$ as well as singlet molecular oxygen could activate the SoxRS regulon in vivo (Manchado et al., 2000; Agnez-Lima et al., 2001).

The products of the induced soxRS regulon include: Mn-superoxide dismutase $(\operatorname{sod} A)$, DNA repair endonuclease IV ( $n f o$ ), glucose-6-phosphate dehydrogenase ( $z w f)$, aconitase $(a c n A)$, stable fumarase $($ fum $C)$, ferredoxin reductase $(f p r)$, toxin and antibiotic efflux pumps $(a c r A B)$, an antisense RNA for the ompF porin mRNA $(m i c F)$ and an iron-binding repressor of iron transport (fur) (Amabile-
Cuevas and Demple, 1991;Gaudu and Weiss, 1996; Gaudu et al., 1997; Pomposiello and Demple, 2001).

\section{Regulation of the OxyRS response to oxidative damage}

Bacterial cells possess an adaptive response to oxidizing agents, which means that exposure to low levels of $\mathrm{H}_{2} \mathrm{O}_{2}$ allows bacterial cells to survive further toxic doses of $\mathrm{H}_{2} \mathrm{O}_{2}$ (Demple and Halbrook, 1983; Demple, 1991). The expression of nine proteins induced by $\mathrm{H}_{2} \mathrm{O}_{2}$ treatment is under the control of the oxyR gene (Christman et al., 1985). Several proteins whose expression is regulated by oxy $R$ have been identified, including catalase and an alkyl hydroperoxide reductase (Morgan et al., 1986; Storz et al., 1990).

The level of OxyR protein does not change with $\mathrm{H}_{2} \mathrm{O}_{2}$ treatment, indicating that it is activated post-translationally (Storz et al., 1990). $\mathrm{H}_{2} \mathrm{O}_{2}$ activates the transcriptional activity of OxyR by oxidizing two of its cysteine residues (Zheng et al., 1998; Aslung et al., 1999; Storz and Toledano, 1999). When activated, OxyR activates transcription of genes that include katG (catalase hydroperoxidase I), $\operatorname{ahpCF}$ (alkylhidroperoxide-NADPH oxido-reductase), grxA (glutaredoxin), gor A (glutathione reductase), dps (a protein that protects DNA from peroxide damage) (Altuvia et al., 1994; Martinez and Kolter, 1997) and fur (an ironbinding repressor of iron transport). Under oxidative-stress conditions with the influence of OxyR and SoxRS, the number of Fur molecules per cell increases from 5,000 to about 10,000 (Zheng et al., 1999).

In addition, OxyR activates the synthesis of oxyS (Altuvia et al., 1997; Zhang et al., 1997), which encodes an untranslated mRNA that appears to regulate as many as 20 additional genes, possibly by an antisense mechanism (Altuvia et al., 1997; Argaman and Altuvia, 2000). The oxyS gene product is independent of OxyR in limiting the endogenous production of $\mathrm{H}_{2} \mathrm{O}_{2}$ in $E$. coli (Gonzalez-Flexa and Demple 1999).

Through random transcriptional fusions some new genes, the expression of which require OxyR, have been detected. These include henF (coproporphyrinogen III oxidase), which participates in the synthesis of photoheme IX, which is required for activity of both HPI ( katG) and HPII (Mukhopadhyay and Schellhorn, 1997). DNA microarray techniques have detected several other new OxyR-activated genes including the henH heme biosynthetic gene; the six-gene suf operon, which may participate in Fe-S cluster assembly of repair; and four genes of unknown function (Zheng et al., 2001).

\section{Cross-Adaptive Responses}

Cross-adaptive response occurs when cells exposed to doses of a sub-lethal agent develop resistance against challenging doses of another lethal agent. For instance, it is 
well known that $E$. coli cells exposed to low doses of $\mathrm{H}_{2} \mathrm{O}_{2}$ develop resistance against heat shock, ethanol (Jenkins et al., 1988), ultraviolet A (UVA) (Tyrrell, 1985), formaldehyde (Nunoshiba et al., 1991), menadione and cumene hydroperoxide (Christman et al., 1985). In contrast, prior exposure of $E$. coli to low doses of $\mathrm{H}_{2} \mathrm{O}_{2}$ has shown little or no effect on the resistance of these cells to UVC or alkylating agents (Demple and Halbrook, 1983). This section is meant to provide a general view into the cross-adaptive response induced by $\mathrm{H}_{2} \mathrm{O}_{2}$ against effects of UV (254 nm), N-methyl-N'-nitro-N-nitrosoguanidine (MNNG) and cumene hydroperoxide.

\section{Cross-adaptive response between $\mathrm{H}_{2} \mathrm{O}_{2}$ and UV $(254 \mathrm{~nm})$}

Demple and Halbrook (1983) have shown that prior exposure of $E$. coli to low doses of $\mathrm{H}_{2} \mathrm{O}_{2}$, in the micromolar range, engenders little or no effect on the resistance of these cells to UV. However, pretreatment with $2.5 \mathrm{mM} \mathrm{H}_{2} \mathrm{O}_{2}$ protected wild-type cells against UV-irradiation. This protection is independent of the SOS response, since it is also observed in a lexA mutant, and is dependent on DNA excision repair, since this protection is not observed in an $u v r A$ mutant (Asad et al., 1994). The possibility that DNA repair activities other than those known to be involved in SOS response could be induced during $\mathrm{H}_{2} \mathrm{O}_{2}$ pretreatment was verified by examining the ability of $\mathrm{H}_{2} \mathrm{O}_{2}$-pretreated cells to repair incoming damaged DNA. In this way, experiments similar to those described by Weigle (1953), but involving treatment of the cells with $2.5 \mathrm{mM} \mathrm{H}_{2} \mathrm{O}_{2}$ instead of UV, were carried out with UV-irradiated phages. An enhanced survival of UV-irradiated phages in the wild-type, $\mathrm{H}_{2} \mathrm{O}_{2}$-pretreated cells has been shown. The same results were obtained with the lexA1 mutant, indicating that the response is not dependent on the SOS system; nevertheless RecA and UvrA proteins are involved, since there is no UV-damaged phage reactivation in $r e c A$ and $u v r A$ mutant cells pretreated with $2.5 \mathrm{mM} \mathrm{H} \mathrm{O}_{2}$. The oxy $\Delta 3$ mutant, in which the adaptive response to $\mathrm{H}_{2} \mathrm{O}_{2}$ does not occur (Imlay and Linn, 1987), presented similar results to those observed in wild-type and the lexA1 mutant, indicating that the oxyR regulon does not participate in the UV-damaged phage repair which takes place in $\mathrm{H}_{2} \mathrm{O}_{2}$-treated cells.

The induction of some proteins after UV irradiation in lexA (Def) mutants has been observed (Lesca et al., 1991), and these proteins may act in mutagenesis and in the DNA repair of UV-irradiated bacteriophage lambda (Calsou et al., 1987). In fact, Petit et al. (1993) have characterized an $E$. coli gene, $\operatorname{din} Y$, whose induction does not require the cleavage of LexA repressor, although it may be considered a member of the SOS regulon (Petit et al., 1993; Friedberg et al., 1995). The protective effect induced by $\mathrm{H}_{2} \mathrm{O}_{2}$ against $\mathrm{UV}$ is shown to be independent of the induction of $\operatorname{din} Y$ gene or other genes under the same control as $\operatorname{din} Y$ (Asad et al., 2000). Besides, this cross-protection re- sponse is not induced when the SOS regulon is constitutively expressed. The most consistent view of these observations seems to be that the induction of this response may be related to the induction of genes that are not under the control of LexA, and are inhibited by the expression of SOS genes (Asad et al., 2000).

\section{Cross-adaptive response between $\mathrm{H}_{2} \mathrm{O}_{2}$ and MNNG}

The Ada and Ogt proteins are involved in the DNA repair of some lesions caused by alkylating agents, as $\mathrm{O}^{6}$-methylguanine and $\mathrm{O}^{4}$-methylthymine. Moreover, Ada induces the expression of different genes such as ada, alkA and $a i d B$ in cells treated with alkylating agents, leading to the development of adaptive responses induced by pretreatment with sublethal concentrations of alkylating agents (Friedberg et al., 1995).

A cross-adaptive response against lethal effects caused by alkylating agents does not occur when cells of $E$. coli are exposed to low doses of $\mathrm{H}_{2} \mathrm{O}_{2}$ (micromolar) (Demple and Halbrook, 1983), but on the other hand, pretreatment with $5 \mathrm{mM} \mathrm{H}_{2} \mathrm{O}_{2}$ protects the wild-type strain, as well as ada, ogt, ada-ogt, alkA and aidB mutants against the lethal effect of MNNG (Assad et al., 1997). Since $\mathrm{H}_{2} \mathrm{O}_{2}$ is able to oxidize thiols (Halliwell and Gutteridge, 1999), which are necessary to convert MNNG into the mutagenic methylnitrosamine (Sedgwick and Robins, 1980), similar experiments were performed with N-nitroso-N-methylurea and N-nitroso-N-ethylurea, which do not require activation by thiols, and the results were similar to those obtained with MNNG (Assad et al., 1997). This protection is accompanied by a reduction in the mutation frequency in the wild-type cells and in the ogt mutant, but not in the ada mutant. So, Ada protein is able to decrease the mutagenic lesions induced by $\mathrm{MNNG}$ in $\mathrm{H}_{2} \mathrm{O}_{2}$-pretreated cells. Horsfall et al. (1990) have shown that the DNA context influences both the distribution and reparability of alkylation damage. This observation may provide information on the cross-adaptive response between $\mathrm{H}_{2} \mathrm{O}_{2}$ and $\mathrm{MNNG}$, since the DNA alkylation pattern induced by MNNG can be altered when the DNA has already been oxidized.

\section{Cross-adaptive response between $\mathrm{H}_{2} \mathrm{O}_{2}$ and cumene hydroperoxide}

Ahp protein expression is under the control of OxyR protein. Ahp plays an important role in protecting bacterial cells against alkyl hydroperoxides, such as cumene hydroperoxide (Storz et al., 1989), and the active enzyme requires the presence of two subunits with molecular weights of $22 \mathrm{kDa}(\mathrm{AhpC})$ and $57 \mathrm{kDa}(\mathrm{AhpF})$.

It has been shown that $2.5 \mathrm{mM} \mathrm{H}_{2} \mathrm{O}_{2}$ pre-treatment protects wild-type cells against cumene hydroperoxide killing (Asad et al., 1998). Unexpectedly, this protection is observed in the oxy $\Delta 3$ mutants, meaning that it is an OxyR-independent phenomenon. The protection is mediated by Ahp protein and there is no requirement for novel 
protein synthesis (Asad et al., 1998). Electrophoretic profile studies of proteins from wild-type cells treated with $\mathrm{H}_{2} \mathrm{O}_{2}(2.5 \mathrm{mM})$ for $20 \mathrm{~min}$ have shown that a $22 \mathrm{kDa}$ protein (possibly Ahp protein) observed in untreated wild-type cells is faintly visible in $\mathrm{H}_{2} \mathrm{O}_{2}$-treated cells. In the latter, instead of the $22 \mathrm{kDa}$ band a $24 \mathrm{kDa}$ band appears. This modification was not observed when wild type was treated with lower concentrations of $\mathrm{H}_{2} \mathrm{O}_{2}$ (micromolar).

It is known that $\mathrm{H}_{2} \mathrm{O}_{2}$ causes modification in several E. coli proteins (Farr and Kogona, 1991). So, these results suggest that millimolar concentrations of $\mathrm{H}_{2} \mathrm{O}_{2}$ might induce an alteration in the electrophoretic profile of the smaller subunit of AhpC (22 kDa). It is important to bear in mind that inhibition of protein synthesis does not prevent the appearance of the $24-\mathrm{kDa}$ band promoted by $\mathrm{H}_{2} \mathrm{O}_{2}$. These results are interpreted to mean that AhpC 22-kDa subunit undergoes conversion to different oxidized forms when challenged with higher doses of $\mathrm{H}_{2} \mathrm{O}_{2}$, resulting in a small alteration of its molecular weight. Since Ahp may prevent oxidative damage and repair lesions caused by active oxygen species (Farr and Kogona, 1991), the AhpC 24 $\mathrm{kDa}$ form can be interfering with the repair of lesions caused by cumene hydroperoxide (Asad et al., 1998).

DNA damage and repair in $E$ coli challenged by $\mathrm{H}_{2} \mathrm{O}_{2}$ in the presence of iron chelators

The protection conferred by iron scavengers against the effect of $\mathrm{H}_{2} \mathrm{O}_{2}$ was first demonstrated by Imlay and Linn (1988). In 1991, Asad and Leitão showed that prior treatment with iron chelators such as o-phenanthroline, dipyridyl and desferrioxamine protected the cells against the $\mathrm{H}_{2} \mathrm{O}_{2}$ lethal effect, but the number of induced DNA-single strand breaks (DNA-SSB) was similar even in the presence of iron chelators. More significantly, the

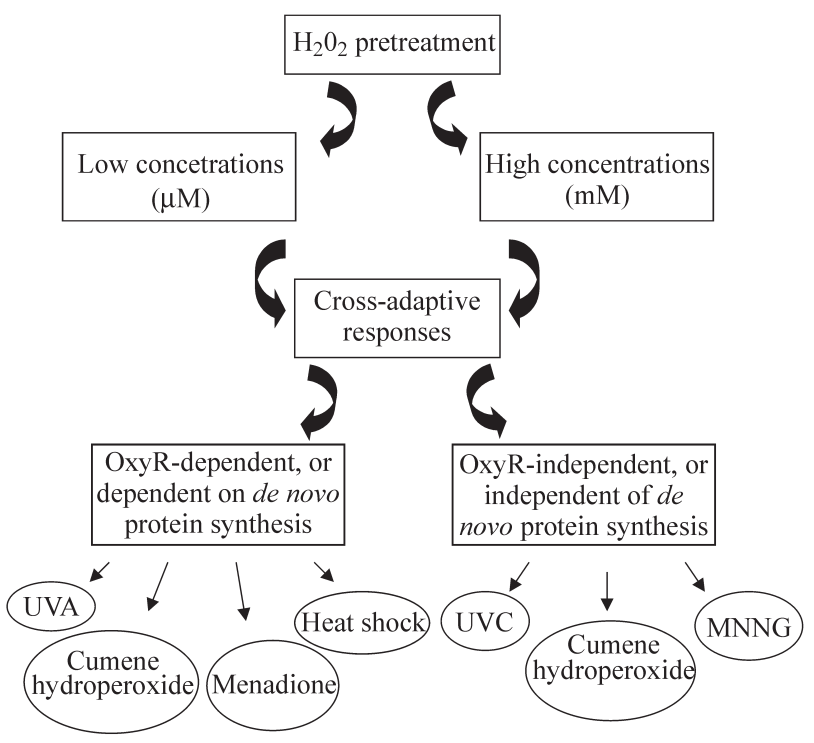

Figure 1 - Cross-adaptive responses induced by low or high $\mathrm{H}_{2} \mathrm{O}_{2}$ concentration operate through different mechanisms. breaks observed after treatment with metal chelators and $\mathrm{H}_{2} \mathrm{O}_{2}$ are repaired 60 min after $\mathrm{H}_{2} \mathrm{O}_{2}$ elimination in $x$ thA but not polA mutant cells (Asad and Leitão, 1991).

Since then, in a series of experiments spanning a full decade, DNA damage and the genetic repair mechanisms of the $\mathrm{H}_{2} \mathrm{O}_{2}$-induced DNA lesions in a low-iron condition, which means cells previously treated with metal-ion chelators, have been examined. Asad et al. (1995) demonstrated a striking hypersensitivity of the fpg and $u v r A$ mutant strains to $\mathrm{H}_{2} \mathrm{O}_{2}$ under low-iron conditions, suggesting that the processing of DNA lesions induced in this situation may occur in a different way from that found under physiological iron conditions.

Other investigations have demonstrated common pathways in the cell response to $\mathrm{H}_{2} \mathrm{O}_{2}$ challenge in a low-iron condition and in physiological iron conditions. SOS and the OxyR pathways are the ones involved in the response of $E$. coli cells subjected to both challenges (Asad et al., 1997).

Evidence for the participation of endonuclease IV (the $n f o$ gene product) in the repair of DNA lesions generated by $\mathrm{H}_{2} \mathrm{O}_{2}$ under low-iron conditions came from studies of the processing of DNA strand breaks in different $E$. coli strains (Galhardo et al., 2000). Survival experiments with $x$ thA, $n f_{\mathrm{o}}$, and $x$ thA $n f o$ mutant strains in which the cultures were treated with $5 \mathrm{mM} \mathrm{H}_{2} \mathrm{O}_{2}$ confirm data previously described in the literature, so that the $x t h A$ mutant was sensitive to $\mathrm{H}_{2} \mathrm{O}_{2}$ (Demple et al., 1983) while the $n f o$ strain was not (Cunningham et al., 1986), and the xthA nfo double mutant was even more sensitive than the $x t h A$ mutant. Experiments with cultures pretreated with dipyridyl showed a distinct pattern of dependence on AP endonucleases for bacterial survival. Neither the $x$ th $A$ nor the $n f o$ single mutants were significantly inactivated by $\mathrm{H}_{2} \mathrm{O}_{2}$ under low-iron conditions. However, the $x$ thA nfo double mutant was highly sensitive to this treatment, indicating that both exonuclease III and endonuclease IV may act in the repair of the oxidative lesions generated under such conditions. Analysis of the sedimentation profile in alkaline sucrose gradients also demonstrated that both $x t h A$ and $n f o$ mutants, but not the $x$ thA nfo double mutant, could carry out complete repair of DNA-SSB generated by $\mathrm{H}_{2} \mathrm{O}_{2}$ under low-iron conditions (Galhardo et al., 2000). Thus, these findings support the idea that both exonuclease III and endonuclease IV act in the repair of DNA damage induced by $\mathrm{H}_{2} \mathrm{O}_{2}$ in iron-depleted $E$. coli, and then strongly suggest that the lesions caused by $\mathrm{H}_{2} \mathrm{O}_{2}$ in the presence of dipyridyl are qualitatively different from those found in the absence of this iron chelator. It is interesting to note that despite the severe repair defect of the $x t h A$ nfo strain, significant levels of repair were observed under both physiological and low-iron conditions. The exact nature of this repair mechanism remains to be elucidated.

Further studies indicated that the formation of substrates for exonuclease III and endonuclease IV is mediated 
by the Fpg DNA glycosylase, since the fpg mutation increases cell survival and repair of DNA strand breaks in a null AP endonuclease background (xthA nfo double mutant). Recently, Speck et al. (2002) showed that the same phenomenon is observed for nitric oxide treatment, that is, in a null AP endonuclease background, fpg and ung mutations are able to increase cell survival.

\section{The role of copper ions in the lethality induced by $\mathrm{H}_{2} \mathrm{O}_{2}$ in low-iron conditions}

Most of the work on the effects of $\mathrm{H}_{2} \mathrm{O}_{2}$ in living organisms has reported that DNA damage induced by $\mathrm{H}_{2} \mathrm{O}_{2}$ can be explained basically by the generation of hydroxyl radicals through the iron-mediated Fenton reaction. Some authors have attributed the same role to copper ions, also present in biological systems (Sagripanti and Kraemer, 1989; Aruoma et al., 1991; Dizdaroglu et al., 1991). The suggested mechanism for this effect takes into account the formation of a DNA- $\mathrm{Cu}^{2+}$ complex in which this metal would be reduced and then the DNA- $\mathrm{Cu}^{+}$would react with $\mathrm{H}_{2} \mathrm{O}_{2}$ to produce oxidative damage, via Fenton-type reactions (Aruoma et al., 1991; Byrnes et al., 1992; Lloyd et al., 1997; Lloyd and Phillips, 1999). Although copper ions seemed not to participate in the genotoxicity of $\mathrm{H}_{2} \mathrm{O}_{2}$ in $E$. coli under physiological iron conditions (Asad and Leitão, 1991), these ions have been shown to take part in the genotoxicity of $\mathrm{H}_{2} \mathrm{O}_{2}$ under conditions of low iron availability. In fact, neocuproine (copper ion chelator) can inhibit cell inactivation and DNA strand breakage caused by $\mathrm{H}_{2} \mathrm{O}_{2}$ in the presence of iron chelators (Almeida et al., 2000). This phenomenon can only be detected in high concentrations of $\mathrm{H}_{2} \mathrm{O}_{2}(15 \mathrm{mM})$, suggesting that these ions only interact with $\mathrm{H}_{2} \mathrm{O}_{2}$ in the intracellular environment in the absence of iron and under severe oxidative stress.

Copper-induced DNA damage has been studied in several systems. It has been demonstrated that such damage is targeted preferentially to adjacent polyguanosines (Aruoma et al., 1991). Analysis of the oxidative base lesions generated by copper-mediated Fenton reactions showed that purine residues are the preferred targets of the DNA-damaging species (Sagripanti and Kraemer 1989; Dizdaroglu et al., 1991; Lloyd and Phillips, 1999], with 8 -oxoG being the most abundant lesion formed. Frelon et al. (2003) have shown that only 8-oxoG is formed upon incubation of DNA with $\mathrm{Cu}(\mathrm{II})$ ions and $\mathrm{H}_{2} \mathrm{O}_{2}$ and suggested that in vitro the Fenton reaction triggered by copper ions generates singlet oxygen as the predominant reactive species, with hydroxyl radical being produced predominantly when the Fenton reaction is triggered by iron ions. In fact, 8-oxoG is the only lesion excised from $\mathrm{H}_{2} \mathrm{O}_{2} / \mathrm{Cu}^{2+}$-treated DNA at detectable levels by the yOgg1 glycosylase from Saccharomyces cerevisiae (Karahalil et al., 1998). The finding of a remarkable increase in mutagenesis in $u \mathrm{v} r A$ fpg-strain cultures pretreated with dipyridyl, and its inhibition by neocuproine (Almeida et al., 2000), strongly sug- gest that 8-oxoG is formed in large amounts by such treatment. The data suggesting a significant role for Fpg and UvrA proteins in the repair of DNA lesions correlate well with the hypothesis of copper participation, since it was demonstrated that these proteins are important in the repair of lesions induced by singlet oxygen, another well-known guanine-damaging agent. Taken together these results may indicate the production of singlet oxygen as the predominant ROS when $E$. coli cultures are challenged with $\mathrm{H}_{2} \mathrm{O}_{2}$ under low-iron conditions.

On the other hand some interesting results were obtained from mutagenesis assays performed by our group (manuscript in preparation) regarding the nature of lesions produced by $\mathrm{H}_{2} \mathrm{O}_{2}$ in cells previously treated with dipyridyl. Using an assay based on $l a c^{-}$reversion through a single base change in mutated lac $Z$ codon (Cupples and Miller, 1989), we found that concentrations of $\mathrm{H}_{2} \mathrm{O}_{2}$ above $15 \mathrm{mM}$ induce almost exclusively $\mathrm{A}: \mathrm{T} \rightarrow \mathrm{T}: \mathrm{A}$ transversions. However, in cells previously treated with dipyridyl a massive and significant presence of $\mathrm{G}: \mathrm{C} \rightarrow \mathrm{A}: \mathrm{T}$ transitions is detected, a clearly different profile of induced mutations. Considering that this transversion is not reported to be induced by 8 -oxoG the authors have suggested that $\mathrm{H}_{2} \mathrm{O}_{2}$ under low-iron conditions may generate the lesion 5-hydroxy-2'-deoxycytidine, a highly mutagenic product of cytosine oxidation that also constitutes a substrate for Fpg repair protein (Hatahet et al., 1994; Feig et al., 1994).

A qualitative difference exists between the DNA lesions generated by $\mathrm{H}_{2} \mathrm{O}_{2}$ plus copper (in the presence of iron chelators) and iron (physiologic iron condition), which can be deduced by the different DNA repair requirements for cell survival in these situations. The reason for this difference is not known, and there exists an as yet unsolved question about the participation of hydroxyl radical in the damage to DNA caused by copper plus $\mathrm{H}_{2} \mathrm{O}_{2}$ (Sagripanti and Kraemer, 1989; Yamamoto and Kawanishi, 1989). Free-radical scavengers partially inhibit $E$. coli inactivation by $\mathrm{H}_{2} \mathrm{O}_{2}$ (Imlay et al., 1988), and we observed that thiourea protects the cells against the lethality produced by $\mathrm{H}_{2} \mathrm{O}_{2}$ both in the presence of dipyridyl (our unpublished results) and in physiological iron conditions (Asad and Leitão, 1991).

\section{Synergistic lethal interactions}

In the last three decades, many studies have been published regarding synergistic lethal effects between $\mathrm{H}_{2} \mathrm{O}_{2}$ and different physical and chemical agents. Some of them will be described in this section.

\section{Lethal synergism between UV $(254 \mathrm{~nm})$ and $\mathrm{H}_{2} \mathrm{O}_{2}$}

Synergistic lethal interaction between UV (254 nm) and X-ray irradiation, a well known system of generating $\mathrm{H}_{2} \mathrm{O}_{2}$ and DNA strand breaks was described three decades 
$\mathrm{H}_{2} \mathrm{O}_{2}$ - DNA lesions and DNA repair

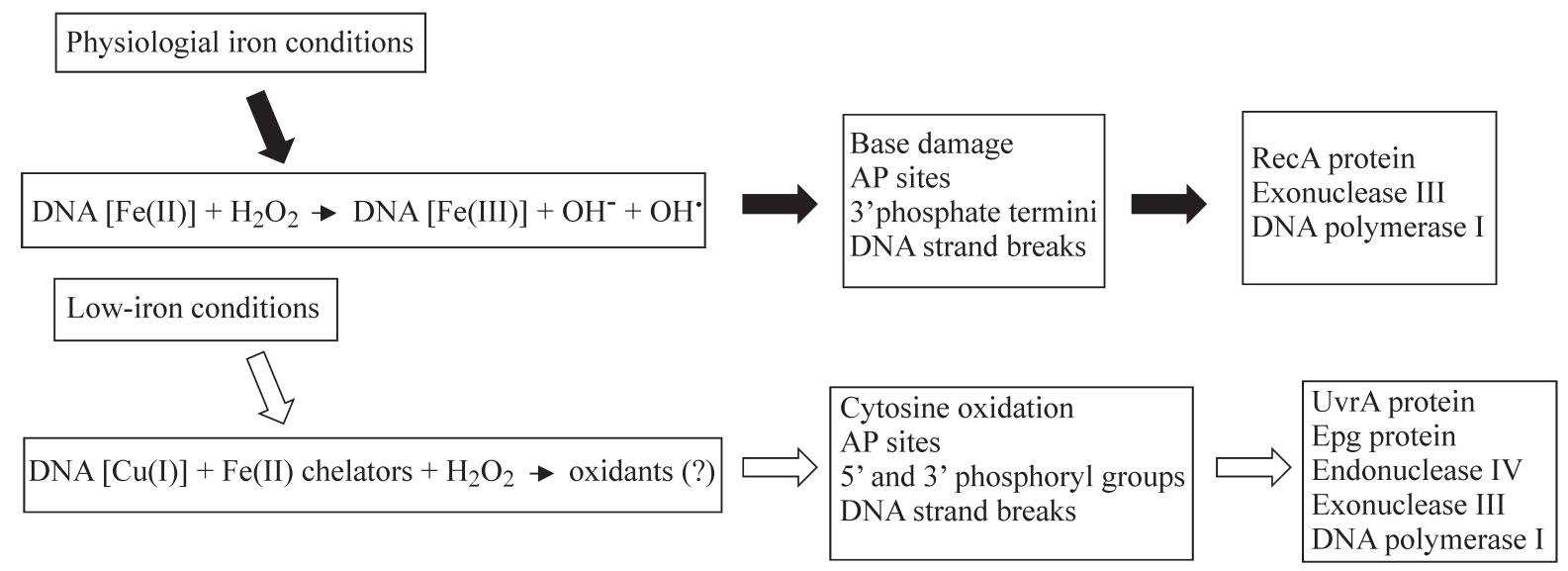

Figure 2 - DNA lesions and DNA repair in physiological and low-iron conditions.

ago in E. coli (Haynes, 1966; Martignoni and Smith, 1973). However, synergistic lethal interaction was not observed between UV (254 $\mathrm{nm}$ ) and $\mathrm{H}_{2} \mathrm{O}_{2}$ (Hartman and Eisenstark, 1980). On the other hand, synergistic killing of E. coli and S. thyphimurium by near-UV (300-400 $\mathrm{nm})$ radiation and $\mathrm{H}_{2} \mathrm{O}_{2}$ has been described (Hartman and Eisenstark, 1978; Hartman and Eisenstark, 1980; Kramer and Ames, 1987).

An analysis of the UV and X-ray effects (Martignoni and Smith, 1973), the results of repair of $\mathrm{H}_{2} \mathrm{O}_{2}$ lesions in several mutant strains (Ananthaswany and Eisenstark, 1977), and our own results for UV and reductone (an $\mathrm{H}_{2} \mathrm{O}_{2}$-generating keto-aldehyde) (Leitão et al., 1981a; Leitão et al., 1981b) suggested that a synergistic lethal interaction between UV and $\mathrm{H}_{2} \mathrm{O}_{2}(254 \mathrm{~nm})$ should be observed. Indeed, Leitão and Carvalho (1988) observed that prior UV $(254 \mathrm{~nm})$ irradiation strongly increased the sensitivity to $\mathrm{H}_{2} \mathrm{O}_{2}$ of wild-type $E$. coli cells, and this synergistic lethal interaction was also observed to a reduced extent in a pol $A$ mutant, suggesting that UV lesions are potentiated by the additional damage produced by $\mathrm{H}_{2} \mathrm{O}_{2}$, a result similar to those observed by Martignoni and Smith (1973) for UV and X-rays.

The detection of DNA double-strand breaks by DNA sedimentation on neutral sucrose gradients (Leitão and Carvalho, 1988) clearly indicates a mechanism responsible for the synergistic lethal interaction observed. Although $\mathrm{H}_{2} \mathrm{O}_{2}$ can produce DNA strand breaks with low efficiency (Demple and Linn, 1982), the repair of UV lesions by the action of the $u v r$ gene products generated single-stranded DNA regions and it was supposed that, in the presence of $\mathrm{H}_{2} \mathrm{O}_{2}$, DNA double-strand breaks might arise in these regions, produced by the action of exonuclease III (the $x t h A$ gene product). This hypothesis was confirmed by the absence of synergistic lethal interaction between UV (254 $\mathrm{nm})$ and $\mathrm{H}_{2} \mathrm{O}_{2}$ in $x t h A$ as well as in $u v r A$ mutant strains (Leitão and Carvalho, 1988). It seems that the same kind of mechanism may be operating in the synergisms observed with near-UV and $\mathrm{H}_{2} \mathrm{O}_{2}$, UV and reductone and UV and X-rays.

\section{Lethal synergism between phenanthrolines and $\mathrm{H}_{2} \mathrm{O}_{2}$}

As described earlier, prior treatment with iron chelators such as desferrioxamine, dipyridyl or o-phenanthroline (1,10-phenanthroline) protects $E$. coli cells against the lethal effects of $\mathrm{H}_{2} \mathrm{O}_{2}$. However, Asad et al. (1994) detected a strong lethal interaction when $x$ th $A$ mutant cells were treated simultaneously with $\mathrm{H}_{2} \mathrm{O}_{2}$ and o-phenanthroline. In the same way Almeida et al. (1999) have also detected a lethal synergistic interaction between neocuproine (2,9-dimethyl 1,10-phenanthroline) and $\mathrm{H}_{2} \mathrm{O}_{2}$. In both cases the phenomenon of synergism was accompanied by an increase in the number of DNA strand breaks.

In the case of the synergism described by Asad et al. (1994), it was argued that the formation and dissociation equilibrium of $\mathrm{Fe}^{2+}$-Phe complex, which follows equations IV, V and VI (Lee et al., 1948) shown below, would explain the observed phenomenon.

$$
\begin{array}{llll}
\mathrm{Fe}^{2+}+\mathrm{Phe} \rightarrow \mathrm{FePhe}^{2+} & \begin{array}{l}
\text { rapidly established equi- } \\
\text { librium }
\end{array} \\
\mathrm{FePhe}^{2+}+\mathrm{Phe} \rightarrow \mathrm{FePhe}_{2}^{2+} & \begin{array}{l}
\text { rapidly established equi- } \\
\text { librium }
\end{array} \\
\mathrm{FePhe}_{2}{ }^{2+}+\mathrm{Phe} \rightarrow \mathrm{FePhe}_{3}{ }^{2+} & \text { rate-determining step }
\end{array}
$$

Since the equilibrium of the bis and mono complexes of $\mathrm{Fe}^{2+}$-Phe are rapidly established and since these bis and mono complexes react quickly with $\mathrm{H}_{2} \mathrm{O}_{2}$ (Burgers and Prince, 1965), there would be $\mathrm{H}_{2} \mathrm{O}_{2}$-mono and $\mathrm{H}_{2} \mathrm{O}_{2}$-bis complex formation and these complexes may be extremely lethal to the cells, therefore justifying the lethal interaction observed. In this case, the ability of o-phenanthroline to penetrate into the DNA duplex, acting as a shuttle for the $\mathrm{Fe}^{2+}$ ions would increase the efficiency of $\mathrm{OH}$ generation close to DNA (Furtado et al., 1997). Recently Furtado (2002) showed that this interaction also occurs in vitro. By 
using plasmid DNA, he showed that the high number of breaks, as measured by the transformation of supercoiled to relaxed form, is obtained when iron and o-phenanthroline are added to the reaction medium immediately before $\mathrm{H}_{2} \mathrm{O}_{2}$.

As mentioned above, Almeida et al. (1999) showed that prior incubation of $f p g, u v r A$ and $\operatorname{lex} A$ mutant strains with neocuproine led to an increased sensitivity to $\mathrm{H}_{2} \mathrm{O}_{2}$. The chemistry of this synergistic lethal interaction was suggested to occur via the iron-mediated Fenton reaction, which would be responsible for displacement of copper ions from the complex $\mathrm{NeO}_{2} \mathrm{Cu}^{+}$, as Florence et al., (1985) have reported to occur in vitro. In fact, neocuproine, as well as other phenanthroline derivatives, have the ability to penetrate into DNA, guiding metal ions to this site, which can contribute to radical formation in the vicinity of this molecule (Furtado et al., 1997). Indeed, it is possible that neocuproine can guide copper ions to the DNA molecule, thereby promoting the occurrence of radical generation at this site as $\mathrm{H}_{2} \mathrm{O}_{2}$ reacts with these ions.

\section{Conclusions}

The most remarkable outcome from the genetic studies on $\mathrm{H}_{2} \mathrm{O}_{2}$-mediated genotoxicity is the striking sensitivity of $x$ th $A$ mutant $E$. coli cells to $\mathrm{H}_{2} \mathrm{O}_{2}$. In fact, this observation provides some insights into the nature of $\mathrm{H}_{2} \mathrm{O}_{2}$-induced lesions. Nevertheless, it is important to realize that the oxidative stress produced by $\mathrm{H}_{2} \mathrm{O}_{2}$ results in the induction of a diverse set of physiological responses, which include some paradoxical effects. In this context, the most unexpected phenomenon investigated so far is the bimodal pattern of inactivation of $E$. coli by $\mathrm{H}_{2} \mathrm{O}_{2}$ described by Imlay and Linn (1986). In the same way, it is now evident that although pre-treatment of E. coli $x$ thA cultures with iron chelators confers protection against the lethal effects of $\mathrm{H}_{2} \mathrm{O}_{2}$, DNA lesions can still be formed under these conditions. We have to keep in mind that in contrast with what is observed in the repair of damage induced by $\mathrm{H}_{2} \mathrm{O}_{2}$ under physiological iron conditions, after treatment with $\mathrm{H}_{2} \mathrm{O}_{2}$ in low-iron conditions: (i) the lesions observed may be repaired in $x$ thA mutant cells (ii) both endonuclease IV and exonuclease III as well as Fpg and UvrA proteins participate in the repair of these lesions. Such a difference in the repair suggests a qualitative difference in the formation of DNA lesions that is independent of the presence of iron. Iron chelators partially inhibit $E$. coli inactivation by $\mathrm{H}_{2} \mathrm{O}_{2}$. However, the precise mechanism for the genotoxic effect of $\mathrm{H}_{2} \mathrm{O}_{2}$ under low-iron conditions remains to be elucidated. It is also curious to see that some metal-ion chelators such as o-phenanthroline and neocuproine, which should generally inhibit the lethal effect of $\mathrm{H}_{2} \mathrm{O}_{2}$ can sometimes enhance cell inactivation. Moreover, the data available so far suggest that $\mathrm{H}_{2} \mathrm{O}_{2}(2.5 \mathrm{mM})$ can induce protection against UV light, MNNG and cumene hydroperoxide independently of the adaptive response, indicating that $\mathrm{H}_{2} \mathrm{O}_{2}$ can produce crossprotection responses through various mechanisms that might not involve the induction of de novo protein synthesis.

\section{Acknowledgements}

We thank C.F.M. Menck, D.P. Carvalho and M. Sorenson for critical reading of this manuscript. Research supported by CNPq, CAPES, FUJB, FAPERJ and PRONEX.

\section{References}

Agnez-Lima LF, Di Mascio P, Demple B and Menck CFM (2001) Singlet molecular oxygen triggers the soxRS regulon of Escherichia coli. Biol Chem 382:1071-1075.

Almeida CEB, Felício DL, Galhardo RS, Cabral-Neto JB and Leitão AC (1999) Synergistic lethal effect between hydrogen peroxide and neocuproine (2,9-dimethyl 1,10-phenanthroline) in Escherichia coli. Mutat Res 433:59-66.

Almeida CEB, Galhardo RS, Felício DL, Cabral-Neto JB and Leitão AC (2000) Copper ions mediate the lethality induced by hydrogen peroxide in low iron conditions in Escherichia coli. Mutat Res 460:61-67.

Altuvia S, Almiron M, Huisman G, Kolter R and Storz G (1994) The $d p s$ promoter is activated by OxyR during growth and by IHF and $\sigma^{\mathrm{s}}$ in stationary phase. Mol Microbiol 13:265272.

Altuvia S, Weinstein-Fischer D, Zhang A, Postow L and Storz G (1997) A small, stable RNA induced by oxidative stress: role as a pleiotropic regulator and antimutator. Cell 90:43-53.

Amabile-Cuevas CF and Demple B (1991) Molecular characterization of the soxRS genes of Escherichia coli: two genes control a superoxide stress regulon. Nucleic Acids Res 19:4479-4484.

Ames BN, Shigenaga MK and Hagen TM (1993) Oxidants, antioxidants and the degenerative diseases of aging. Proc Natl Acad Sci USA 90:7915-7922.

Ananthaswamy HN and Eisenstark A (1977) Repair of hydrogen peroxide-induced single-strand breaks in E. coli deoxyribonucleic acid. J Bacteriol 130:187-191.

Argaman L and Altuvia S (2000) fhlA repression by OxyS RNA: kissing complex formation at two sites results in a stable antisense-target RNA complex. J Mol Biol 300:1101-1112.

Aruoma OI, Halliwell B, Gajewski E and Dizdaroglu M (1991) Copper-ion-dependent damage to the bases in DNA in the presence of hydrogen peroxide. Biochem J 273:601-604.

Asad LMBO, Almeida CEB, Silva AB, Asad NR and Leitão AC (1994) Hydrogen peroxide induces the repair of UVdamaged DNA in Escherichia coli: A lexA-independent but $u v r A$ - and recA-dependent mechanism. Curr Microbiol 29:291-294.

Asad LMBO, Asad NR, Silva AB, Almeida CEB and Leitão AC (1997) Role of SOS and OxyR systems in the repair of Escherichia coli submitted to hydrogen peroxide under low iron conditions. Biochimie 79:359-364.

Asad LMBO, Asad NR, Silva AB, Felzenszwalb I and Leitão AC (1997) Hydrogen peroxide induces protection against Nmethyl-N'-nitro-N-nitrosoguanidine (MNNG) effects in Escherichia coli. Mutat Res 383:137-142. 
Asad LMBO, De Carvalho AA, Felzenszwalb I, Leitão AC and Asad NR (2000) $\mathrm{H}_{2} \mathrm{O}_{2}$-induced cross-protection against UV-C killing in Escherichia coli is blocked in a lexA (Def) background. J Phochem Photobiol (B) 54:67-71.

Asad NR, Almeida CEB, Asad LMBO, Felzenswalb I and Leitão AC (1995) Fpg and UvrA proteins participate in the repair of DNA lesions induced by hydrogen peroxide in low iron level in Escherichia coli. Biochimie 77:262-264.

Asad NR, Asad LMBO, Almeida CEB and Leitão AC (1994) Lethal interaction between hydrogen peroxide and o-phenanthroline in Escherichia coli. Braz J Med Biol Res 27:2551-2555.

Asad NR, Asad LMBO, Silva AB, Felzenszwalb I and Leitão AC (1998) Hydrogen peroxide induces protection against lethal effects of cumene hydroperoxide in Escherichia coli cells: An Ahp independent but OxyR dependent system? Mutat Res 407:253-259.

Asad NR and Leitão AC (1991) Effects of metal ion chelators on DNA strand breaks and inactivation produced by hydrogen peroxide in Escherichia coli: Detection of iron-independent lesions. J Bacteriol 173:2562-2568.

Aslund F, Zheng M, Beckwith J and Storz G (1999) Regulation of OxyR transcription factor by hydrogen peroxide and the cellular thiol-disulfide status. Proc Natl Acad Sci USA 96:6161-6165.

Bjelland S and Seeberg E (2003) Mutagenicity, toxicity and repair of DNA base damage induced by oxidation. Mutat Res 531:37-80.

Blaisdell JA, Hatahet Z and Wallace SS (1999) A novel role for Escherichia coli endonuclease VIII in prevention of spontaneous G T transversions. J Bacteriol 181:6396-6402.

Boiteux S and Huisman O (1989) Isolation of a formamidopyrimidine-DNA glycosylase $(f p g)$ mutant of Escherichia coli K-12. Mol Gen Genet 215:300-305.

Brakely WF, Fuciarelli AF, Wegher BJ and Dizdaroglu M (1990) Hydrogen peroxide-induced base damage in deoxyribonucleic acid. Radiat Res 121:338-343.

Brandi G, Cattabeni F, Albano A and Cantoni C (1989) Role of hydroxyl radicals in Escherichia coli killing induced by hydrogen peroxide. Free Radic Res Commun 6:47-55.

Braun V (1997) Avoidance of iron toxicity through regulation of bacterial iron transport. Biol Chem 378:779-786.

Braun V, Hantke K and Koster W (1998) Bacterial ion transport: mechanisms, genetics and regulation. In Sigel A and Sigel H (eds) Metal Ions in Biological Systems. Marcel Dekker, New York, NY, pp 67-145.

Burgers J and Prince RH (1965) Kinetics of reactions of ligandsubstitued tris-(2-2'-dipyridyl) iron (II) complexes. J Chem Soc 1132:6061-6066.

Byrnes RW, Antholine WE and Petering DH (1992) Oxidationreduction reactions in Ehrlich cells treated with copperneocuproine. Free Rad Biol Med 13:469-478.

Cadet J, Douki T, Gasparuto D and Ravanat J-L (2003) Oxidative damage to DNA: Formation, measurement and biochemical features. Mutat Res 531:5-23.

Calsou P, VillaVerde A and Defais M (1987) Activated RecA protein may induced expression of gene that is not controlled by the LexA repressor and whose function is record for mutagenesis and repair of UV-irradiated bacteriophage lambda. J Bacteriol 169:4816-4821.
Chan E and Weiss B (1987) Endonuclease IV of Escherichia coli is induced by paraquat. Proc Natl Acad Sci USA 84:31893193.

Chaudhry MA, Dedon PC, Wilson DM III, Demple B and Weinfeld M (1999) Removal by human apurinic/apirimidinic endonuclease 1 (Ape1) and Escherichia coli exonuclease III of 3'-phosphoglycolates from DNA treated with neocarzinostatin, calicheamicin and gamma-radiation. Biochem Pharmacol 57:531-538.

Christman MF, Morgan RW, Jacobson FS and Ames BN (1985) Positive control of a regulon for defenses against oxidative stress and some heat-shock proteins in Salmonella typhimurium. Cell 41:753-762.

Cooke MS, Evans MD, Dizdaroglu M and Lunec J (2003) Oxidative DNA damage: Mechanisms, mutation, and disease. FASEB J 17:1195-1214.

Courcelle J, Khoudursky A, Peter B, Brown PO and Hanawalt PC (2001) Comparative gene expression profiles following UV exposure in wild-type and SOS-deficient Escherichia coli. Genetics 158:41-64.

Cunningham RP, Saporito SM, Spitzer SG and Weiss B (1986) Endonuclease IV (nfo) mutant of Escherichia coli. J Bacteriol 168:1120-1127.

Cunningham RP and Weiss B (1985) Endonuclease III (nth) mutants of Escherichia coli. Proc Natl Acad Sci USA 82:474478.

Cupples C and Miller, J (1989) A set of lacZ mutations in Escherichia coli which allow rapid detection of each of the six base substitutions. Proc Natl Acad Sci USA 86:5345-5349.

Demple B (1991) Regulation of bacterial oxidative stress genes. Annu Rev Genet 25:315-337.

Demple B and Halbrook J (1983) Inducible repair of oxidative DNA damage in Escherichia coli. Nature 304:466-468.

Demple B, Halbrook J and Linn S (1983) Escherichia coli xth mutants are hypersensitive to hydrogen peroxide. J Bacteriol 153:1079-1082.

Demple B and Harrison L (1994) Repair of oxidative DNA damage to DNA: Enzymology and biology. Annu Rev Biochem 63:915-948.

Demple B and Linn S (1982) 5,6-saturated thymine lesions in DNA: Production by ultraviolet light and hydrogen peroxide. Nucleic Acid Res 10:3781-3789.

Dizdaroglu M (2003) Substract specificities and excision kinetics of DNA glycosylases involved in base-excision repair of oxidative DNA damage. Mutat Res 531:109-126.

Dizdaroglu M, Rao G, Halliwell B and Gajewski E (1991) Damage to the DNA bases in mammalian chromatin by hydrogen peroxide in the presence of ferric and cupric ions, Arch Biochem Biophys 285:317-324.

Farr SB and Kogoma T (1991) Oxidative stress responses in Escherichia coli and Salmonella typhimurium. Microbiol Rev 55:561-585.

Feig DI, Sowers LC and Loeb LA (1994) Reverse chemical mutagenesis: Identification of the mutagenic lesions resulting from reactive oxygen species-mediated damage to DNA. Proc Natl Acad Sci USA 91:6609-6613.

Fernandez De Henestrosa AR, Ogi T, Aoyagi S, Chafin D, Hayes JJ, Ohmori H and Woodgate R (2000) Identification of additional genes belonging to the lexA regulon in Escherichia coli. Mol Microbiol 35:1560-1572. 
Florence TM, Stauber JL and Mann KJ (1985) The reaction of copper-2,9-dimethyl-1,10-phenanthroline with hydrogen peroxide. J Inorg Biochem 23:243-254.

Frelon S, Douki T, Favier A and Cadet J (2003) Hydroxyl radical is not the main reactive species involved in the degradation of DNA bases by copper in the presence of hydrogen peroxide, Chem Res Toxicol 16:191-197.

Friedberg EC, Walker GC and Siede W (1995) DNA Repair and Mutagenesis. Academic Press, New York, 698 pp.

Furtado FAC (2002) Caracterização adicional do fenômeno de interação letal entre 1,10-fenantrolina e peróxido de hidrogênio em Escherichia coli. PhD Thesis, Universidade Federal do Rio de Janeiro, Rio de Janeiro.

Furtado FAC, Asad NR and Leitão AC (1997) Effects of 1,10phenanthroline and hydrogen peroxide in Escherichia coli: Lethal interaction. Mutat Res 385:251-258.

Galhardo RS, Almeida CEB, Leitão AC and Cabral-Neto JB (2000) Repair of DNA lesions induced by hydrogen peroxide in the presence of iron chelators in Escherichia coli: Participation of endonuclease IV and Fpg. J Bacteriol 182:1964-1968.

Gaudu P, Moon N and Weiss B (1997) Regulation of the soxRS oxidative stress regulon. Reversible oxidation of the Fe-S centers of SoxR in vivo. J Biol Chem 272:5082-5086.

Gaudu P and Weiss B (1987) SoxR a [2Fe-2S] transcription factor, is active only in its oxidized form. Proc Natl Acad Sci USA 84:3189-3193.

Geenberg JT and Demple B (1989) A global response induced in Escherichia coli by redox-cycling agents overlaps with that induced by peroxide stress. J Bacteriol 171:3922-3939.

Goerlich O, Quillardet P and Hofnung M (1989) Induction of the SOS response by hydrogen peroxide in various Escherichia coli mutants with altered protection against oxidative DNA damage. J Bacteriol 171:6141-6147.

Gonzalez-Flecha B and Demple B (2000) Genetic responses to free radicals. Homeostasis and gene control. Ann New York Acad Sci 899:69-87.

Hagensee ME and Moses RE (1989) Multiple pathways for repair of hydrogen peroxide-induced DNA damage in Escherichia coli. J Bacteriol 171:991-995.

Halliwell B and Gutteridge JMC (1984) Oxygen toxicity, oxygen radicals, transition metals and disease. J Biochem 219:1-14.

Halliwell B and Gutteridge JMC (1999) Free Radicals In Biology and Medicine. Oxford University Press, New York, 936 pp.

Hanawalt PC (2001) Controling the efficiency of excision repair. Mutat Res 485:3-13.

Hantke K (1981) Regulations of ferric ion transport in Escherichia coli $\mathrm{K} 12$ : Isolation of a constitutive mutant. Mol Gen Genet 182:288-292.

Hantke K (2002) Members of the Fur protein family regulate iron and zinc transport in E. coli and characteristics of the Furregulated fhuF protein. J Mol Microbiol Biotechnol 4:217-222.

Hartman PS and Eisenstark A (1978) Synergistic killing of Escherichia coli by near-UV radiation and hydrogen peroxide. Distinction between RecA-repairable and RecA-nonrepairable damage. J Bacteriol 133:769-774.

Hartman PS and Eisenstark A (1980) Killing of Escherichia coli $\mathrm{K}-12$ by near-ultraviolet radiation in the presence of hydrogen peroxide: Role of double-strand breaks in absence of recombinational repair. Mutat Res 72:31-42.
Hatahet Z, Kow YW, Purmal AA, Cunninghan RP and Wallace SS (1994) New substrates for old enzymes. 5-hydroxy2'-deoxicytidine and 5-hydroxy-2'-deoxyuridine are substrates for Escherichia coli endonuclease III and formamidopyrimidine DNA N-glycosylase, while 5-hydroxy-2'deoxyuridine is a substrate for uracil DNA N-glycosylase. J Biol Chem 269:18814-18820.

Haynes RH (1966) The interpretation of microbial inactivation and recovery phenomena. Radiat Res Suppl 6:1-29.

Henle ES and Linn S (1997) Formation, prevention and repair of DNA damage by iron/hydrogen peroxide. J Biol Chem 272:19095-19098.

Hidalgo E, Bollinger Jr JM, Bradley TM, Walsh CT and Demple B (1995) Binuclear [2Fe-2S] clusters in the Escherichia coli SoxR protein and role of the metal centers in transcription. $\mathrm{J}$ Biol Chem 270:20908-20914.

Hidalgo E, Ding H and Demple B (1997) Redox signal transduction mutations shifting $[2 \mathrm{Fe}-2 \mathrm{~S}]$ centers of SoxR sensorregulated to the oxidized form. Cell 88:121-129.

Horsfall MJ, Gordon JE, Burns PA, Zielenska M, Van der Viet GME and Glickman BW (1990) Mutational specificity of alkylating agents and the influence of DNA repair. Environ Mol Mut 15:107-122.

Imlay JA, Chin SM and Linn S (1988) Toxic DNA damage by hydrogen peroxide through the Fenton reaction in vivo and in vitro. Science 240:640-642.

Imlay JA and Linn S (1986) Bimodal pattern of killing of DNArepair-defective or anoxically grown Escherichia coli by hydrogen peroxide. J Bacteriol 166:519-527.

Imlay JA and Linn S (1987) Mutagenesis and stress responses induced in Escherichia coli by hydrogen peroxide. J Bateriol 169:2967-2976.

Imlay JA and Linn S (1988) DNA damage and oxygen radical toxicity. Science 240:1302-1309.

Izumi T, Hazra TK, Boldogh I, Tomkinson AE, Park MS, Ikeda S and Mitra S (2000) Requeriment for human AP endonuclease 1 for repair of 3'-blocking damage at DNA singlestrand breaks induced by reactive oxygen species. Carcinogenesis 21:1329-1334.

Jenkins DE, Schultz JE and Martin A (1988) Starvation-induced cross protection against heat or $\mathrm{H}_{2} \mathrm{O}_{2}$ challenge in Escherichia coli. J Bacteriol 170:3910-3914.

Jiang D, Hatahet Z, Blaisdell JO, Melamede RJ and Wallace SS (1997) Escherichia coli endonuclease VIII: Cloning, sequencing, and overexpression of the nei structural gene and characterization of nei and nei nth mutants. J Bacteriol 179:3773-3782.

Karahalil B, Girard PM, Boiteux S and Dizdaroglu M (1998) Substrate specificity of the Ogg1 protein of Saccharomyces cerevisiae: excision of guanine lesions produced in DNA by ionizing radiation-or hydrogen peroxide/metal iongenerated free radicals. Nucleic Acids Res 26:1228-1232.

Kehrer JP (2000) The Haber-Weiss reaction and mechanisms of toxicity. Toxicology 149:43-50.

Konola JT, Sargent KE and Gow JB (2000) Efficient repair of hydrogen peroxide-induced DNA damage by Escherichia coli requires SOS induction of RecA and RuvA proteins. Mutat Res 459:187-194.

Kow YW, Wallace SS and Van Houten B (1990) UvrABC nuclease complex repairs thymine glycol, an oxidative DNA base damage. Mutat Res 235:147-156. 
Kramer GF and Ames BN (1987) Oxidative mechanisms of toxicity of low-intensity near-UV light in Salmonella typhimurium. J Bacteriol 169:2259-2266.

Kruszewski M (2003) Labile iron pool: the main determinant of cellular responses to oxidative stress. Mutat Res 531:81-92.

Lee TS, Kolthoff IM and Leusing DL (1948) Reaction of ferrous and ferric ions with 1,10-phenanthroline. II. Kinetics of formation and dissociation of ferrous phenanthroline. J Am Chem Soc 70:3596-3600.

Leitão AC, Caldas LR and Alcantara Gomes R (1981a) Inhibition of DNA repair and production of single-strand breaks in Escherichia coli by reductone. Photochem Photobiol 34:49-53.

Leitão AC and Carvalho RES (1988) Synergistic killing of Escherichia coli $\mathrm{K}-12$ by $\mathrm{UV}(254 \mathrm{~nm})$ and $\mathrm{H}_{2} \mathrm{O}_{2}$. Int J Radiat Biol 53:477-488.

Leitão AC, Motta HC and Alcantara Gomes R (1981b) Kinetics of DNA-induced breaks by reductone treatment: in vitro and in vivo studies. Photochem Photobiol 34:745-748.

Lesca C, Petit C and Defais M (1991) UV induction of lexA independent proteins which could be involved in SOS repair. Biochimie 73:407-409.

Lin JJ and Sancar A (1989) A new mechanism for repairing oxidative damage to DNA: (A)BC exonuclease removes AP sites and thymine glycols from DNA. Biochemistry 28:79797984.

Lloyd DR and Phillips DH (1999) Oxidative DNA damage mediated by copper(II), iron(II) and nickel(II) Fenton reactions: evidence for site-specific mechanisms in the formation of double-strand breaks, 8-hydroxydeoxyguanosine and putative intrastrand cross-links. Mutat Res 424:23-36.

Lloyd DR, Phillips DH and Carmichael PL (1997) Generation of putative intrastrand cross-links and strand breaks in DNA by transition metal ion-mediated oxygen radical attack. Chem Res. Toxicol 10:393-400.

Manchado M, Michán C and Pueyo C (2000) Hydrogen peroxide activates the SosRS regulon in vivo. J Bacteriol 182:68426844.

Martignoni KD and Smith KC (1973) The synergistic action of ultraviolet and X-radiation on mutants of Escherichia coli K-12. Photochem Photobiol 18:1-8.

Martinez A and Kolter R (1997) Protection of DNA during oxidative stress by the nonspecific DNA-binding protein Dps. J Bacteriol 179:5188-5194.

Melamede RJ, Hatahet Z, Kow IW, Ide H and Wallace SS (1994) Isolation and characterization of endonuclease VIII from Escherichia coli. Biochemistry 33:1255-1264.

Mello-Filho AEC and Meneghini R (1985) Protection of mammalian cells by o-phenanthroline from lethal and DNAdamaging effects produced by active oxygen species. Biochim Biophys Acta 847:82-89.

Meneghini R (1987) A toxicidade do oxigênio. Ci Hoje 5:57-62.

Meneghini R (1988) Genotoxicity of active oxygen species in mammalian cells. Mutat Res 195:215-230.

Miles GM and Sancar A (1989) DNA repair. Chem Res Toxicol 2:197-226.

Mol CD, Hosfield DJ and Tainer JA (2000) Abasic site recognition by two apurinic/apyrimidinic endonucleases families in DNA base excision repair: the 3' ends justify the means. Mutat Res 460:211-229.
Morgan RW, Christman MF, Jacobson FS, Storz G and Ames BN (1986) Hydrogen peroxide-inducible proteins in Salmonella typhimurium overlap with heat shock and other stress proteins. Proc Natl Acad Sci USA 83:8059-8063.

Mukhopadhyay S and Schellhorn HE (1997) Identification and characterization of hydrogen peroxide-sensitive mutants of Escherichia coli: Genes that require OxyR for expression. J Bacteriol 179:330-338.

Mustard JA and Little JW (2000) Analysis of Escherichia coli RecA interactions with LexA, lambda CI, and UmuD by site-directed mutagenesis of recA. J Bacteriol 182:16591670.

Nunoshiba T, Hashimoto M and Nishioka H (1991) Crossadaptive response in Escherichia coli caused by pretreatment with $\mathrm{H}_{2} \mathrm{O}_{2}$ against formaldehyde and other aldehyde compounds. Mutat Res 255:265-271.

Petit C, Cayrol C, Lesca C, Kaiser P, Thompson C and Defais M (1993) Characterization of $\operatorname{din} Y$, a new Escherichia coli DNA repair gene whose products are damage inducible even in a lexA (Def.) background. J Bacteriol 175:642-646.

Piersen CE, McCullough AK and Lloyd RS (2000) AP lyases and dRPases: commonality of mechanism. Mutat Res 459:4353.

Pomposiello PJ and Demple B (2001) Redox-operated genetic switches: the SoxR and OxyR transcription factors. Trends Biotechnol 19:109-114.

Repine JE, Fox RB and Berger EM (1981) Hydrogen peroxide kills Staphylococcus aureus by reacting with staphylococcal iron to form hydroxyl radical. J Biol Chem 256:7094-7096.

Repine JE, Pfenniger OW, Talmage DW, Berger EM and Pettijohn DE (1981) Dimethyl sulfoxide prevents DNA nicking mediated by ionizing radiation or iron/hydrogen peroxide-generated hydroxyl radical. Proc Natl Acad Sci USA 78:1001-1003.

Sagripanti JL and Kraemer KH (1989) Site-specific oxidative DNA damage at polyguanosines produced by copper plus hydrogen peroxide. J Biol Chem 264:1729-1734.

Sancar A and Sancar GB (1988) DNA repair enzymes. Ann Rev Biochem 57:29-67.

Saporito SM, Gedenk M and Cunningham RP (1989) Role of exonuclease III and endonuclease IV in repair of pyrimidine dimers initiated by bacteriophage $\mathrm{T} 4$ pyrimidine dimmerDNA glycosylase. J Bacteriol 171:2542-2548.

Sayto Y, Uraki F, Nakajima S, Asaeda A, Ono K, Kubo K and Yamamoto K (1997) Characterization of endonuclease III (nth) and endonuclease VIII (nei) mutants of Escherichia coli K-12. J Bacteriol 179:3783-3785.

Sedgwick B and Robins P (1980) Isolation of mutants of Escherichia coli with increased resistance to alkylating agents: Mutants deficient in thiols and mutants constitutive for the adaptive response. Molec Gen Genet 180:85-90.

Spek EJ, Vuong LN, Matsuguchi T, Marinus MJ and Engelward BP (2002) Nitric oxide-induced homologous recombination in Escherichia coli is promoted by DNA glycosylases. J Bacteriol 184:3501-3507.

Storz G, Jacobson FS, Tartaglia LA, Morgan RW, Silveira LA and Ames BN (1989) An Alkyl hydroperoxide reductase induced by oxidative stress in Salmonella typhimurium and Escherichia coli: Genetic characterization and cloning of ahp. J Bacteriol 171:2049-2055. 
Storz G and Imlay JA (1999) Oxidative stress. Curr Opin Microbiol 2:188-194.

Storz G, TartagliaLA and Ames BN (1990) Transcriptional regulator of oxidative stress-inducible genes: Direct activation by oxidation. Science 248:189-194.

Storz G ands Toledano MB (1994) Regulation of bacterial gene expression in response to oxidative stress. Methods Enzymol 236:196-207.

Touati D, Jacques M, Tardat B, Bouchard L and Despied S (1995) Lethal oxidative damage and mutagenesis are generated by iron in fur mutants of Escherichia coli: Protective role of superoxide dismutase. J Bacteriol 177:2305-2314.

Tsaneva IR and Weiss B (1990) soxR, a locus governing a superoxide response regulon in Escherichia coli K-12. J Bacteriol 172:4197-4205.

Tyrrell RM (1985) A common pathway for protection of bacteria against damage by solar UV(A) $(334 \mathrm{~nm}, 365 \mathrm{~nm})$ and an oxidizing agent $\left(\mathrm{H}_{2} \mathrm{O}_{2}\right)$. Mutat Res 145:129-136.

Wagner J, Cruz P, Kim SR, Yamada M, Matsui K, Fuchs RP and Nohmi T (1999) The dinB gene encodes a novel E. coli DNA polymerase, DNA pol IV, involved in mutagenesis. Mol Cell 4:281-286.

Walker GC (1996) The SOS responses of Escherichia coli. In: Curtis III R, Ingraham JL, Lin ECC, Low KB, Magasanick B, Reznicoff WS, Riley M, Schaechter M and Umbarger HE (eds) Escherichia coli and Salmonella typhimurium: Cellular and Molecular Biology. v. 1, American Society for Microbiology, Washington DC, pp 1400-1416.

Wallace SS (1988) Ap endonucleases and DNA glycosylases that recognize oxidative DNA damage. Environ Mol Mutagen $12: 431-477$
Wallace SS (2002) Biological consequences of free radicaldamaged DNA bases. Free Rad Biol Med 33:1-14.

Wallace SS, Ide H, Kow YM, Laspia MF, Melamede RJ, Petrullo LA and LeClerc E (1988) Processing of oxidative DNA damage in Escherichia coli. In: Fridberg EC and Hanawalt PC (eds) Mechanisms and Consequences of DNA Damage Processing. Allan R. Liss, Inc., New York, pp 151-157.

Weigle JJ (1953) Induction of mutation in a bacterial virus. Proc Natl Acad Sci USA 39:628-636.

West SC (1996) The RuvABC proteins and Holliday junctions processing in Escherichia coli. J Bacteriol 178:1237-1241.

Wu J and Weiss B (1992) Two-stage induction of the soxRS (superoxide response) regulon of Escherichia coli. J Bacteriol 174:3915-3920.

Yamamoto K and Kawanishi S (1989) Hydroxyl radical is not the main active species in site-specific DNA damage induced by copper (II) ion and hydrogen peroxide. J Biol Chem 264:15435-15440.

Zhang A, Altuvia S and Storz G (1997) The novel oxyS RNA regulates expression of the sigma s subunit of Escherichia coli RNA polymerase. Nucleic Acids Symp Ser 36:27-28.

Zheng M, Aslund F and Storz G (1998) Activation of OxyR transcription factor by reversible disulfide bond formation. Science 279:1718-1721.

Zheng M, Doan B, Schneider TD and Storz G (1999) OxyR and SoxRS regulation of fur. J Bacteriol 181:4639-4643.

Zheng M, Wang X, Templeton LR, Smulski DR, Larossa RA and Storz G (2001) DNA microarray-mediated transcriptional profiling of the Escherichia coli response to hydrogen peroxide. J Bacteriol 183:4562-4570.

EditorAssociado: Carlos F.M. Menck 